\title{
Evaluation of the strength of concretes produced with recycled CDW aggregates originating from a housing project located in Pernambuco, Brazil
}

\author{
Avaliação da resistência de concretos produzidos com agregados reciclados de RCD oriundos de \\ obra de conjunto habitacional situado em Pernambuco, Brasil \\ Evaluación de la resistencia de hormigones producidos con áridos RCD reciclados provenientes de \\ un proyecto habitacional ubicado en Pernambuco, Brasil
}

Received: 04/02/2021 | Reviewed: 04/11/2021 | Accept: 04/15/2021 | Published: 04/27/2021

Renan Gustavo Pacheco Soares

ORCID: https://orcid.org/0000-0002-6366-9663

Universidade Federal de Pernambuco, Brazil E-mail: renangpsoares@hotmail.com

Gustavo Gutierrez de Oliveira Rodrigues ORCID: https://orcid.org/0000-0001-8617-0120

Universidade Regional de Blumenau, Brazil

E-mail: gustavogutierrez01@hotmail.com

Emylle Kerolayne Palmeira de Andrade

ORCID: https://orcid.org/0000-0001-9492-587X Autarquia do Ensino Superior de Garanhuns, Brazil

E-mail: emyllekerolayne_10@hotmail.com

Carla Renata Xavier Pacheco

ORCID: https://orcid.org/0000-0003-0064-9339 Autarquia do Ensino Superior de Garanhuns, Brazil

E-mail: carla_renatax@hotmail.com

Lyneker Souza de Moura

ORCID: https://orcid.org/0000-0002-9343-6916

Universidade Federal de Pernambuco, Brazil E-mail: lyneker@gmail.com

Kaike Manoel Barros do Nascimento

ORCID: https://orcid.org/0000-0002-8127-3005 Autarquia do Ensino Superior de Garanhuns, Brazil E-mail: kaike41@hotmail.com

Priscila Honório Apolônio

ORCID: https://orcid.org/0000-0003-4820-868X Universidade Federal de Pernambuco, Brazil

E-mail: priscilahonorio@aesga.edu.br

Arnaldo Manoel Pereira Carneiro

ORCID: https://orcid.org/0000-0002-4279-7156

Universidade Federal de Pernambuco, Brazil

E-mail: arnaldo.carneiro@ufpe.br

Romilde Almeida de Oliveira

ORCID: https://orcid.org/0000-0002-6786-9080

Universidade Federal de Pernambuco, Brazil

E-mail: romildealmeida@gmail.com

\begin{abstract}
In view of the improvement of construction techniques and technological innovations, civil construction still faces numerous problems. Uncontrolled exploitation of natural resources has caused major environmental impacts, in addition to the generation and accumulation of debris in urban areas. Thus, recycling appears as a sustainable alternative to reduce the accumulation of this waste. As an option, there is the use of Recycled Aggregates, obtained through Construction and Demolition Waste (CDW). In this sense, the present study aimed to analyze the feasibility of using the CDW through its application in the production of recycled coarse aggregates in concrete. For the tests, the coarse aggregate was replaced in the proportions of 0 (reference line), 10, 20, 30, 40, 50 and 100\%, with three samples for each line and age. The dosage of the strokes followed the parameters established by the IPT / EPUSP method. The concretes were analyzed for compressive strength at 7, 14 and 28 days and the samples were evaluated for properties in an anhydrous, fresh and hardened state. The data collected in the tests were tabulated and analyzed for the degree of addition and its correlation with the characteristic resistance. The results allowed to conclude that the use of the
\end{abstract}


residue in the form of aggregate for the concrete, in the proportions of $10 \%$ and $20 \%$, does not affect the compressive strength, making it a good alternative.

Keywords: Construction and demolition waste; Concrete; Recycled aggregate.

\section{Resumo}

Diante do aprimoramento das técnicas construtivas e inovações tecnológicas, a construção civil ainda enfrenta inúmeros problemas. A exploração sem controle dos recursos naturais tem causado grandes impactos ambientais, além da geração e acúmulo de montantes de entulhos nas áreas urbanas. Assim, surge a reciclagem como uma alternativa sustentável para reduzir o acúmulo desses resíduos. Como opção, tem-se a utilização de Agregados Reciclados, obtidos através dos Resíduos da Construção e Demolição (RCD). Neste sentido, o presente estudo teve como objetivo analisar a viabilidade de utilização do RCD por meio da sua aplicação na produção de agregados graúdos reciclados em concretos. Para a realização dos ensaios, substituiu-se o agregado graúdo nas proporções de 0 (traço referência), 10, 20, 30, 40, 50 e 100\%, com três amostras para cada traço e idade. A dosagem dos traços seguiu os parâmetros estabelecidos pelo método IPT/EPUSP. Os concretos foram analisados quanto a resistência à compressão, aos $7,14 \mathrm{e}$ 28 dias e as amostras foram avaliadas no tocante às propriedades no estado anidro, fresco e endurecido. Os dados coletados nos ensaios foram tabulados e analisados quanto ao grau de adição e sua correlação com a resistência característica. Os resultados permitiram concluir que o uso do resíduo na forma de agregado para o concreto, nas proporções de $10 \%$ e 20\%, não afetam a resistência à compressão, tornando-se uma boa alternativa.

Palavras-chave: Resíduos da construção e demolição; Concreto; Agregado reciclado.

\section{Resumen}

En vista de la mejora de las técnicas de construcción y las innovaciones tecnológicas, la construcción civil aún enfrenta numerosos problemas. La explotación descontrolada de los recursos naturales ha provocado grandes impactos ambientales, además de la generación y acumulación de escombros en áreas urbanas. Así, el reciclaje aparece como una alternativa sostenible para reducir la acumulación de este residuo. Como opción, existe el uso de Áridos Reciclados, obtenidos a través de Residuos de Construcción y Demolición (RCD). En este sentido, este estudio tuvo como objetivo analizar la viabilidad de utilizar el RCD a través de su aplicación en la producción de áridos gruesos reciclados en hormigón. Para las pruebas, el agregado grueso se reemplazó en las proporciones de 0 (línea de referencia), 10, 20, 30, 40, 50 y 100\%, con tres muestras por cada línea y edad. La dosificación de los golpes siguió los parámetros establecidos por el método IPT / EPUSP. Se analizó la resistencia a la compresión de los hormigones a $\operatorname{los} 7,14$ y 28 días y se evaluaron las propiedades de las muestras en estado anhidro, fresco y endurecido. Los datos recogidos en las pruebas se tabularon y analizaron en cuanto al grado de adición y su correlación con la resistencia característica. Los resultados permitieron concluir que la utilización del residuo en forma de árido para el hormigón, en las proporciones de $10 \%$ y $20 \%$, no afecta la resistencia a la compresión, por lo que es una buena alternativa.

Palabras clave: Residuos de construcción y demolición; Hormigón; Agregado reciclado.

\section{Introduction}

The accelerated process of urbanization of urban centers due to population growth has contributed to the significant increase in the generation of construction waste. According to the Brazilian Association for the Recycling of Civil Construction and Demolition Waste (ABRECON, 2016), approximately 66\% of the volume of solid urban waste is composed of civil construction waste, equivalent to twice the volume of household waste.

Due to the great problem in relation to solid waste management, Resolution No. 307 of the National Environment Council (CONAMA, 2002) arises, which imposes on waste generators the correct disposal and disposal of Construction and Demolition Waste (CDW), instituting that they cannot be disposed of in landfills of household waste, in areas of discard, slopes, bodies of water, empty lots or in places protected by law, such as in areas of permanent reserve and legal reserves.

These residues generate a high environmental impact, ranging from the consumption of natural resources and landscape modification, to illegal dumping in landfills, the banks of rivers and streams or in vacant lots.

The recycling of solid waste is a sustainable alternative for the disposal of rubbish. Because, in addition to reducing the chances of disposal in clandestine locations and contributing to mitigate the demand in landfills, it represents lower costs and enables the reuse of materials previously discarded.

As an option, there is the use of Recycled Aggregates (RA), obtained through the CDW. The use of this material for making concrete follows a line of rationalization of the use of materials and management of solid waste, which is an 
attenuating instrument for reducing waste that consequently increases the profit of companies, adding environmental and socioeconomic values (Evagelista, Costa \& Zanta, 2010).

In this sense, the present study aimed to analyze the feasibility of recycling construction and demolition waste, from its use as coarse aggregate, in total and partial replacement to the natural aggregate commonly used, for making concrete. These aggregates come from a housing project located in the countryside of Pernambuco.

\section{Waste from Civil Construction and Demolition}

A large amount of waste resulting from the construction of new buildings, as well as the demolition of old buildings, is generated annually. In addition, a significant amount of rubble is generated in regions affected by natural disasters (Xiao, Zhang \& Akbarnezhad, 2018).

In the civil construction activity, construction and demolition waste is generated in three stages: during construction, maintenance and demolition. The causes that generate these residues are related to several factors, such as the lack of quality of the goods and services performed, disordered urbanization and poorly elaborated projects (Leite, 2001).

The CDW does not present a pattern of composition or homogeneity, since each work uses different materials during different stages of its execution. In this sense, from the analyzes carried out in the Brazilian market on the composition of the CDW generating source, Silva (2014) came to the conclusions shown in Figure 1.

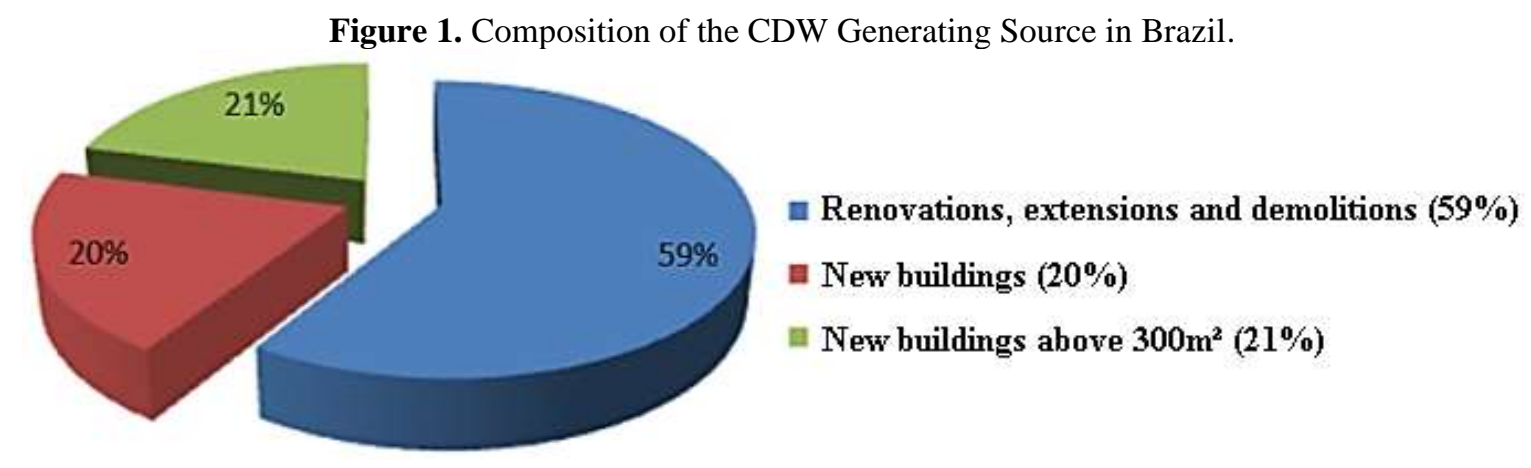

Source: Silva (2014).

It is observed that the largest volumes of waste generated in Brazil are due to reforms, extensions and demolitions. This is a higher index than that of new construction.

In general, the levels of technological development in each region and the construction company that will carry out the project have an influence on the volume of waste produced. Since they take into account the quality of materials, the qualification of the workforce, as well as the operational processes adopted and techniques for controlling the construction process (Cabral \& Moreira, 2011).

For John and Agopyan (2013), solid waste production control procedures require a continuous improvement in the quality of the construction process. In order to minimize maintenance interventions to correct pathologies, through flexible projects that allow changes to be made to buildings. In addition to projects that include the disassembly and reuse of components that are no longer needed at a certain stage of the work at another stage of the construction process.

\section{Concrete with Recycled Aggregate}

According to Karpinsk et al. (2009), the recycling process has great relevance for the preservation of the environment, since these RCD residues will be used again in the construction process, instead of new raw materials, which would be 
extracted from nature. The use of recycled CDW aggregates for the production of concrete, represents a great potential, in addition, researches focused on the application of this type of aggregate, are of paramount importance so that the professionals of the civil construction can apply this type of material in the works (Frotté et al., 2017).

For the use of this material as aggregate in concretes, it is necessary to carry out experimental tests, which define the amount of water necessary to guarantee the consistency and workability of the mixture, as well as to characterize the materials, in order to know their properties, in order to achieve the desired resistance at a compatible cost (Aragão et al., 2007).

\subsection{Properties of recycled concrete}

As they do not undergo chemical reactions when they come into contact with water, the aggregates are considered to be an inert material. However, some of its main properties, such as porosity, granulometric composition, absorption, texture and shape, influence the properties with concrete, in its anhydrous, fresh and hardened states (Pelissari, 2016).

According to Frotté et al. (2017), concretes developed with recycled CDW aggregate show a decrease in workability and higher cement consumption, due to the high-water absorption. In addition to having a higher void rate. Due to the high absorption, concretes made with recycled aggregates, tend to have a lower abatement than conventional concretes.

The strength and durability parameters of concretes with recycled aggregates are governed not only exclusively by the high porosity of the cementitious paste, but also by the porosity of the aggregate, which can easily exceed $10 \%$. Thus, the main difference between RA concrete and conventional concrete is porosity (Isaia, 2011).

According to Rahal (2007), the compressive strength exhibits a behavior inversely proportional to the a/c ratio. This property is also influenced by the porosity of the materials. Thus, the more porous the materials are, the less they tend to be able to resist loads (Fonseca, 2006). For Otsuki, Miyazato e Yodsudjai (2003), increasing the water content is one of the main ways to mitigate the negative effects of AR on concrete workability. However, an undesirable consequence of this action is the decrease in mechanical strength.

For Leite (2001), the greater fragility of the grain, makes RA the least resistant component of the system composed of aggregate, matrix and transition zone. Thus, this material starts to have a greater influence on the strength of the concrete, and its rupture will possibly occur in this component.

Such behavior was demonstrated by Fonseca (2006) who analyzed the rupture of the RA grains of a specimen subjected to the compressive strength test. The author made specimens using AR of ceramic tile, with different contents of substitution, and found a reduction in the compressive strength.

According to Leite (2001), recycled concrete is more deformable when compared to conventional concrete. This fact is associated with the mortar layer adhered to the concrete surface and greater porosity of the materials that make up the aggregate. For Xiao, Li e Zhang (2005), the elasticity modulus of recycled concrete is lower than that of conventional concrete and decreases as the percentage of substitution increases. In this way, the use of more porous aggregates contributes to the reduction of the modulus of elasticity. For Torgal et al. (2013), this decrease in the modulus of elasticity occurs because, when making the substitution of natural aggregates for recycled ones, more mortar is being incorporated into the concrete mass. This fact, provides greater deformations, and consequently, smaller modules.

\section{Methodology}

This work is an experimental study, according Pereira et al. (2018) and Levy (2001). The procedures were divided in different phases. The first, consisted of processing the material, through the collection of reference specimens, crushing of the material, separation and classification of the samples of the samples used in the research. The second corresponded to the characterization of the aggregates through tests carried out in the laboratory. Third, the specimens were made with contents of 
substitution of 10,20,30,40,50 and $100 \%$ by weight of the natural coarse aggregate for the recycled one. Finally, tests were carried out regarding the compressive strength, in order to compare the compressive strength of conventional concrete, with the concrete produced with different CDW substitutions. In Figure 2 there is a flowchart describing the sequence of procedures adopted to carry out the procedures adopted for the experiments in the laboratory.

Figure 2. Flowchart of the adopted procedures.

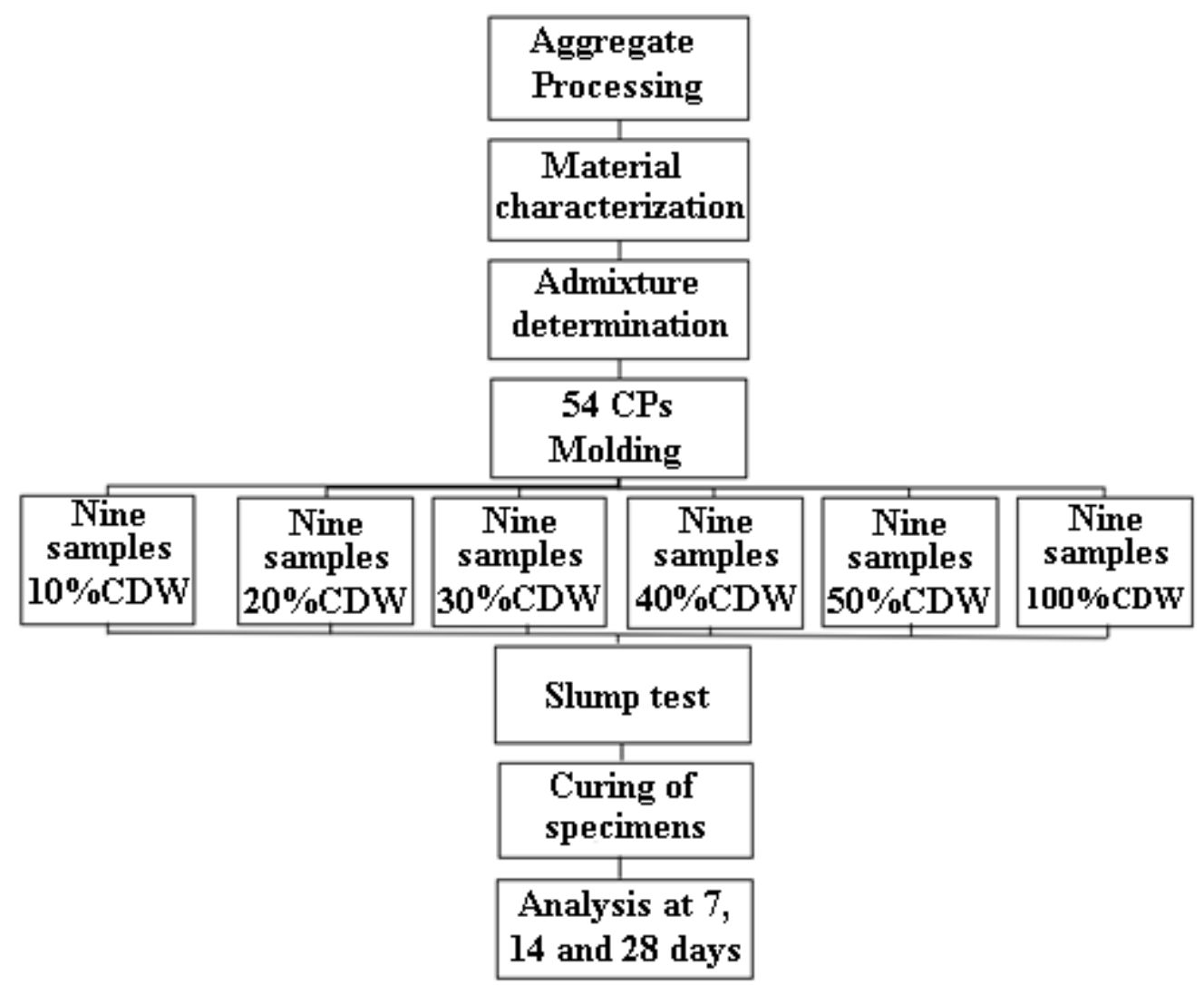

Source: Authors (2020).

The specimens, molded in conventional concrete, were obtained in works located in the municipality of Águas BelasPE. They showed an average compressive strength at 28 days, of $20 \mathrm{MPa}$. This value was used as a parameter to determine the water/cement ratio when measuring the mix for making recycled concrete, as well as serving as a basis for making comparisons with the concrete produced with coarse aggregates of CDW.

\subsection{Materials}

In order to determine the compressive strength, the characterization of the inputs for the preparation of the trace was carried out, according to their properties and the dosage of the materials for making the specimens, which were subsequently subjected to the compression rupture test. For the production of recycled concrete, the following inputs were used: Portland cement CP II-Z-32; Small aggregate: washed sand; Coarse aggregate: gravel $\mathrm{n}^{\circ} 0$ and recycled gravel; Water.

\subsection{Characterization of samples}

The characterization of the materials used in the experimental phase of this research was based on the ABNT standards described in Table 1. 
Table 1. Standards used in the characterization of materials.

\begin{tabular}{ccc}
\hline $\begin{array}{c}\text { STANDARD } \\
\text { (ABNT) }\end{array}$ & TITLE & YEAR \\
\hline NBR NM 248 & Aggregates - Determination of particle size composition & 2003 \\
NBR NM 45 & Aggregates - Determination of unit mass and void volume & 2006 \\
NBR 7211 & Concrete aggregates - Specifications & 2009 \\
NBR NM 53 & Coarse aggregate - Determination of specific gravity, apparent & 2009 \\
\hline
\end{tabular}

Source: Authors (2020).

These standards were used to have a correct characterization of materials and procedures, to obtain reliable results.

\subsubsection{Coarse aggregates}

The coarse recycled aggregate used in this study was obtained from the processing of specimens molded from conventional concrete, with an average compressive strength of $20 \mathrm{MPa}$, obtained in works located in the municipality of Águas Belas-PE. The material was collected and transported to the Materials and Weights Laboratory of the Higher Education Authority of Garanhuns (AESGA). The residues used for making the RA can be seen in Figure 3.

Figure 3. $\mathrm{CP}$ waste for aggregate production.

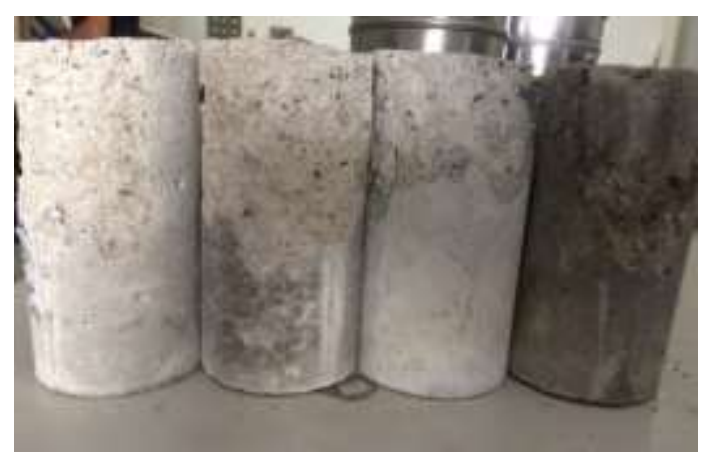

Source: Authors (2020).

The process of obtaining the aggregate was carried out by means of the fragmentation and manual homogenization of the specimens, as can be seen in Figure 3, seeking to reduce the particles of the sample to a granulometry close to the natural gravel used in the experiment, classified as gravel $\mathrm{n}^{\circ} 0$. For the production of the concrete, it used every fraction of material that passed through the $19 \mathrm{~mm}$ mesh sieve and was retained in the $6.30 \mathrm{~mm}$ mesh, as shown in Figure 4.

Figure 4. Crushed material.

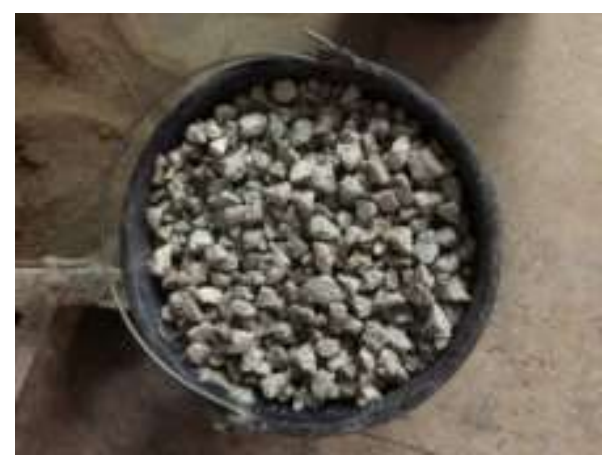

Source: Authors (2020). 
Subsequently, the granulometric compositions of the aggregates were determined following NBR 7211 (ABNT, 2009) and NBR NM 248 (ABNT, 2003). The samples separated for carrying out the test were properly dried in an oven and cooled to room temperature. Subsequently, the previously cleaned screens were fitted to form a single set of screens, with the mesh opening in decreasing order from the top to the bottom. Two samples were sieved, weighing $2 \mathrm{~kg}$, respectively. For the test, the sieves of the normal and intermediate series were used, varying their openings from 25 to $2.36 \mathrm{~mm}$, according to Figure 5 .

Figure 5. Normal and intermediate series.

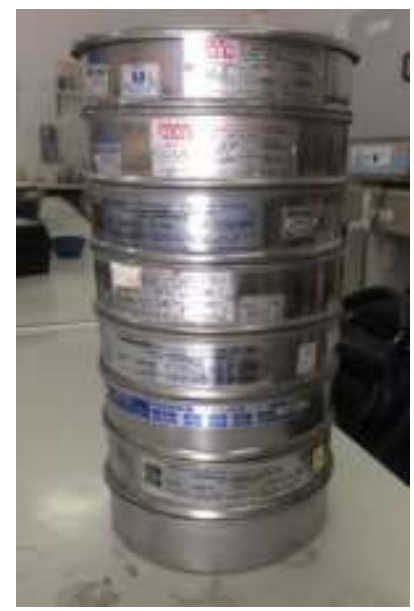

Source: Authors (2020).

The sieves were subjected to manual agitation to carry out the classification of the material. Then the masses retained in each sieve are weighed, and the accumulated percentage of material retained in each one was calculated according to the initial mass of the sample, thus obtaining the necessary data to prepare the graph of the granulometric curve. The coarse aggregate was also subjected to unit mass tests, following NBR NM 45 (ABNT, 2006), and specific mass and water absorption, according to NBR NM 53 (ABNT, 2009).

\subsubsection{Small aggregate}

According to NBR 7211 (ABNT, 2009), small aggregate is defined as the one whose grains pass through the sieve with a $4.75 \mathrm{~mm}$ mesh opening and are retained in the $0.15 \mathrm{~mm}$. Washed sand from the city of Garanhuns - PE, Brazil was used as conventional aggregate (Figure 6).

Figure 6. Conventional aggregate small.

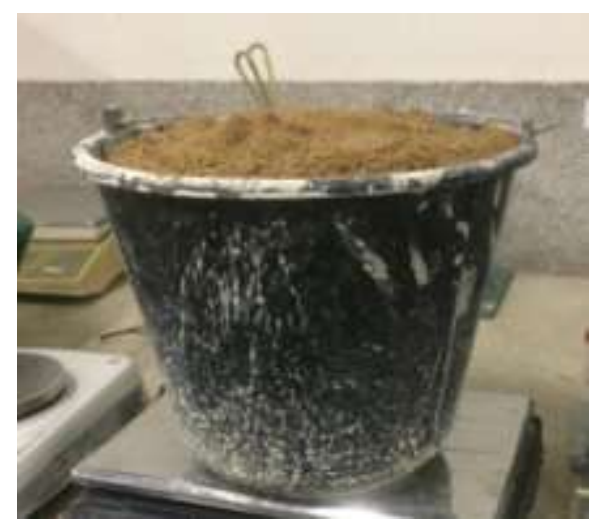

Source: Authors (2020). 
The fine aggregate was subjected to the granulometric analysis characterization test following the prescriptions established in the standards NBR 7211 (ABNT, 2009) and NBR NM 248 (ABNT, 2003), seeking to know which are the parcels made up of grains of each diameter, expressed in depending on the total mass of the aggregate. For the test, a $1 \mathrm{~kg}$ sample of sand was used, dried in an oven and cooled to room temperature, as well as the sieves of the normal series with openings varying from 4.75 to $0.15 \mathrm{~mm}$.

With the results obtained, the granulometric curve was elaborated, with the objective of analyzing whether the sand used in the experiment meets the lower and upper limits established in NBR 7211 (ABNT, 2009). The material was also subjected to the unit mass test, to determine the relationship between its mass and its volume without compacting, also considering the voids between the grains, as specified in NBR NM 45 (ABNT, 2006).

\subsubsection{Absorption}

The determination of the absorption content of coarse aggregates was obtained based on NBR NM 53 (ABNT, 2009). Initially, the material was dried in an oven at a constant temperature of $105 \pm 5^{\circ} \mathrm{C}$, with the intention of removing dust or any other substance from the surface. It was subsequently cooled to room temperature during the $1 \mathrm{~h}$ period.

A micro processed drying oven was used, covered internally in stainless steel, with paint made in electrostatic epoxy, reaching a temperature range of up to $200^{\circ} \mathrm{C}$. It has a programmable digital temperature controller.

The mass used to perform the test was determined according to the maximum characteristic dimension of the material, obtained from the granulometric composition. For RA, the mass of tested sample was $3 \mathrm{~kg}$ and for the natural aggregate $2 \mathrm{~kg}$.

The samples, after drying in an oven, were weighed and subsequently submerged in water at room temperature for a period of 24 hours. Taken out of the water, they were dried on an absorbent cloth, until all visible water was eliminated, however, keeping the surface of the particles moist.

In this way, the aggregate used was in its saturated and dry surface condition. Afterwards, the samples were weighed again and thus the results were obtained regarding the water absorption content of the coarse aggregates.

\subsubsection{Portland Cement}

For the production of concretes, Portland CP II-Z-32 cement was used in this research, composed with the addition of pozzolanic material, as it is commonly used in the region.

This type of cement has several application possibilities. Its properties can serve from reinforced concrete structures, to mortars for covering and laying. CP II-Z-32 contains, in its composition, from 6 to $14 \%$ of pozzolana and up to $10 \%$ of carbonate material (ABCP, 2019).

\subsection{Test methods}

For carrying out the procedures for molding the specimens, the curing process and the compressive strength test, the ABNT norms, described in Table 2, were taken as a basis. 
Table 2. Standards used in the execution of the experiments.

\begin{tabular}{ccc}
\hline $\begin{array}{c}\text { STANDARD } \\
\text { (ABNT) }\end{array}$ & TITLE & YEAR \\
\hline NBR NM 67 & Concrete - Determination of consistency by cutting the cone trunk & 1998 \\
NBR 5738 & Concrete - Procedure for molding and curing specimens & 2015 \\
NBR 12655 & Portland cement concrete - Preparation, control, receipt and & 2015 \\
NBR 5739 & acceptance - Procedure & 2018 \\
\hline
\end{tabular}

Source: Authors (2020).

The concrete dosing was carried out according to the parameters established in the IPT / EPUSP method (Helene \& Tutikian, 2011).

\subsubsection{Production of specimens}

The preparation of the specimens involved the steps of calculating the mix, preparing the concrete, molding the material, curing process and compression test. It was determined, based on the reference values, that the concretes developed would have a characteristic compressive strength of 20 MPa. For this, the IPT/EPUSP method (Helene \& Terzian, 1993) was adopted to define the admixture.

According to the characteristic compressive strength of $20 \mathrm{MPa}$ and from the parameters defined by NBR 12655 (ABNT, 2015), the value of 4.0 MPa was defined as standard deviation. From these references, an average resistance of $26.60 \mathrm{MPa}$ and a water / cement ratio of 0.63 were obtained, an abatement of $100 \mathrm{~mm} \pm 20 \mathrm{~mm}$ was also defined.

The procedure begins with the definition of the appropriate proportions of the ideal dry mortar content $(\alpha)$, based on practical attempts and observations, with successive additions of mortar to the mixture. At first, a mortar content of 54\% was determined, however in the slump test, a lack of cohesion and segregation of the mixture was found, which did not reach the specified abatement.

With the increase in the mortar content to $57 \%$, there was an improvement in the visual aspect of the concrete mixture, which presented a compact and more homogeneous surface. In this way, this was the ideal content chosen, with a dry matter ratio of 1: 6 . Thus, the trait studied was 1: 2.99: 3.01: 0.63 . Table 3 shows the traces obtained for each of the substitutions.

Table 3. Traces calculated from the dosage study.

\begin{tabular}{|c|c|c|c|c|c|c|c|c|}
\hline \multirow{2}{*}{$\begin{array}{l}\text { Substitution } \\
\text { content }\end{array}$} & \multicolumn{5}{|c|}{ Unit Trait } & \multirow[b]{2}{*}{$\mathbf{m}$} & \multirow[b]{2}{*}{$\alpha(\%)$} & \multirow[b]{2}{*}{$\mathbf{H}(\%)$} \\
\hline & Cement & Sand & $\begin{array}{c}\text { Natural } \\
\text { aggregate }\end{array}$ & $\begin{array}{l}\text { Recycled } \\
\text { aggregate }\end{array}$ & $\mathbf{w} / \mathbf{c}$ & & & \\
\hline RA $-10 \%$ & 1 & 2,99 & 2,71 & 0,30 & 0,63 & \multirow{6}{*}{6} & \multirow{6}{*}{0,57} & \multirow{6}{*}{9,00} \\
\hline RA $-20 \%$ & 1 & 2,99 & 2,41 & 0,60 & 0,63 & & & \\
\hline $\mathbf{R A}-\mathbf{3 0 \%}$ & 1 & 2,99 & 2,11 & 0,90 & 0,63 & & & \\
\hline RA $-40 \%$ & 1 & 2,99 & 1,81 & 1,20 & 0,63 & & & \\
\hline RA-50\% & 1 & 2,99 & 1,51 & 1,51 & 0,63 & & & \\
\hline $\mathbf{R A}-\mathbf{1 0 0 \%}$ & 1 & 2,99 & 0,00 & 3,01 & 0,63 & & & \\
\hline
\end{tabular}

Source: Authors (2020).

The used symbology of the RA type is the percentage of recycled aggregate in the mixture. The quantities of materials used in the mix are exactly the same, what differs is only the proportions of the coarse aggregate in each mix. The water/cement ratio also does not change. The preparation of the concrete was carried out mechanically, with the help of the concrete mixer, as shown in Figure 7. 
Figure 7. Concrete preparation.

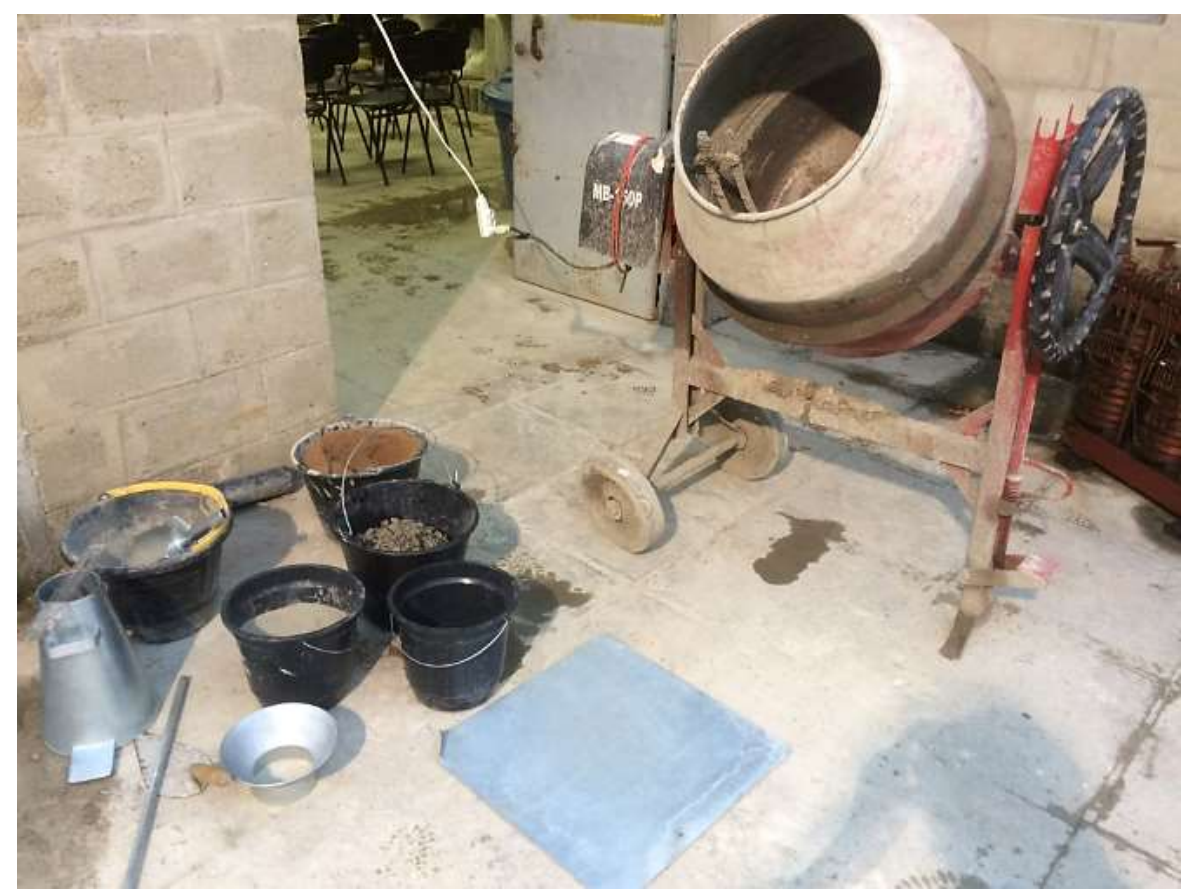

Source: Authors (2020).

These materials were used to preparation of the admixtures. Before start of concrete preparation process, ARs were previously saturated for a period of $10 \mathrm{~min}$. The water used to carry out the previous saturation of aggregates should not be considered in calculation of the water/cement ratio for this type of concrete, when used to perform mechanical strength comparisons with a reference concrete. This because the water/cement ratio tends to be higher than it actually is (Isaia, 2011).

\subsubsection{Slump Test}

After the concrete preparation steps, the cone trunk slump test, also known as the Slump Test, was carried out in accordance with the NBR NM 67 (ABNT, 1998). To perform the test, it was necessary to use the correct apparatus, Figure 8, consisting of mold, compacting rod and base plate.

Figure 8. Materials for Slump Test.

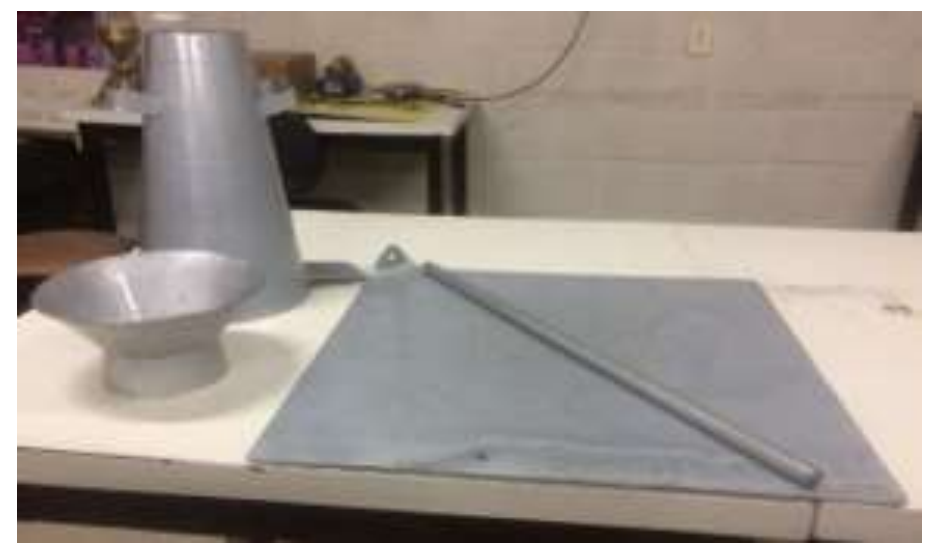

Source: Authors (2020). 
As can be seen in Figure 8, the equipment must be clean and in good conditions to the realization of tests. In accordance with NBR NM 67 (ABNT, 1998), to perform the test it was necessary to initially moisten the mold and the base plate, and position the mold on the plate. During the filling of the mold with the concrete to be tested, it is necessary to keep the feet on the fins in order to keep the conical trunk form stable.

The mold was filled in three layers, each approximately one third of the height of the mold, followed by compacting each layer with 25 strokes with the compacting rod. Then the concrete surface was scraped, and immediately after removing the mold, three measurements of the height between the mold and the top of the concrete pile were made. From these measures, the average was calculated to obtain the discount amount.

\subsubsection{Molding}

The molding of the specimens followed the NBR 5738 (ABNT, 2015), using molds in the dimensions of 10cm in diameter and $20 \mathrm{~cm}$ in height. For these dimensions, the density was made manually and the specimens were molded with two layers, making 12 strokes in each of them. Before proceeding with molding, mold release agent was used in the molds. The molded specimens are shown in Figure 9.

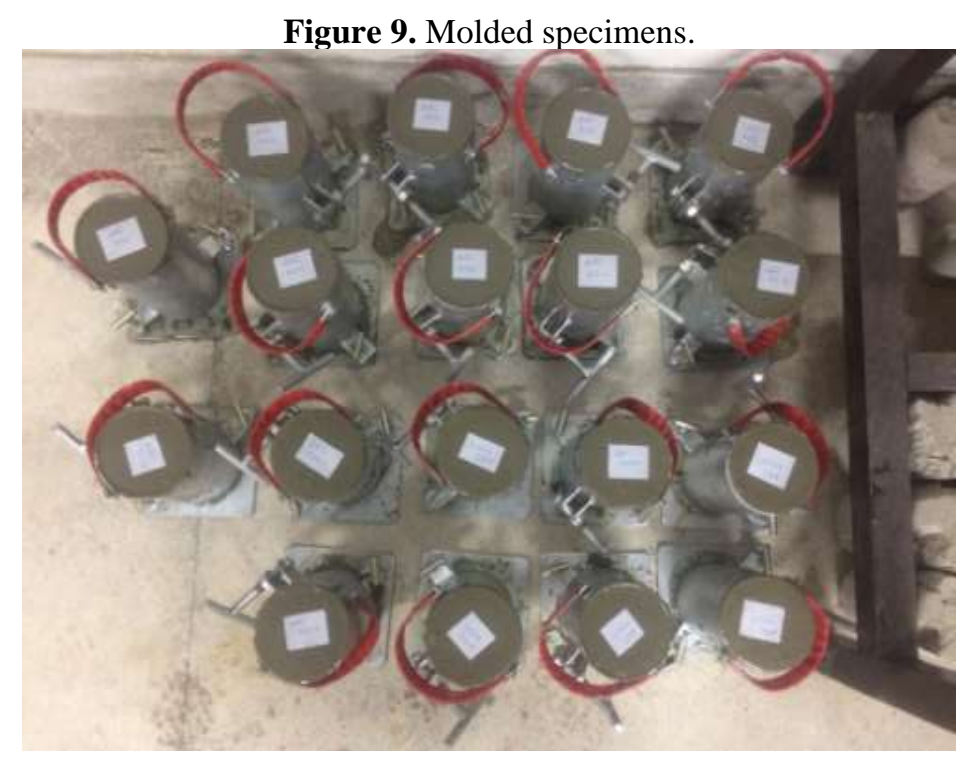

Source: Authors (2020).

In order to carry out the research, a total of 54 specimens were molded, 3 specimens per concrete load, for the tests that will be carried out after 7, 14 and 28 days, periods corresponding to the different stages of curing. The number of molded specimens for each replacement content is shown in Table 4.

Table 4. Number of specimens per replacement.

\begin{tabular}{ccccccc}
\hline \multirow{2}{*}{ Ages } & \multicolumn{6}{c}{ Substitution Contents } \\
\cline { 2 - 7 } & $10 \%$ & $20 \%$ & $30 \%$ & $40 \%$ & $50 \%$ & $100 \%$ \\
\hline $\mathbf{7}$ & 3 & 3 & 3 & 3 & 3 & 3 \\
\hline $\mathbf{1 4}$ & 3 & 3 & 3 & 3 & 3 & 3 \\
\hline $\mathbf{2 8}$ & 3 & 3 & 3 & 3 & 3 & 3 \\
\hline
\end{tabular}

Source: Authors (2020). 
These different ages are necessary to identify the progressive growth of concrete strength samples. After molding, the molds remained on a horizontal surface, free from vibrations for a period of $24 \mathrm{~h}$. After the completion of this initial curing period, the specimens were demolded and placed on wet curing.

The curing of the specimens is performed according to reasons, hydrate the cement and decrease the shrinkage by drying the concrete, factors that are directly related to durability.

In addition, it serves as measure to prevent the water used in the mixing from evaporating, ensuring that the constituent components of cement are hydrated. The specimens in the tank for the wet curing process are shown in Figure 10.

Figure 10. Wet curing of specimens.

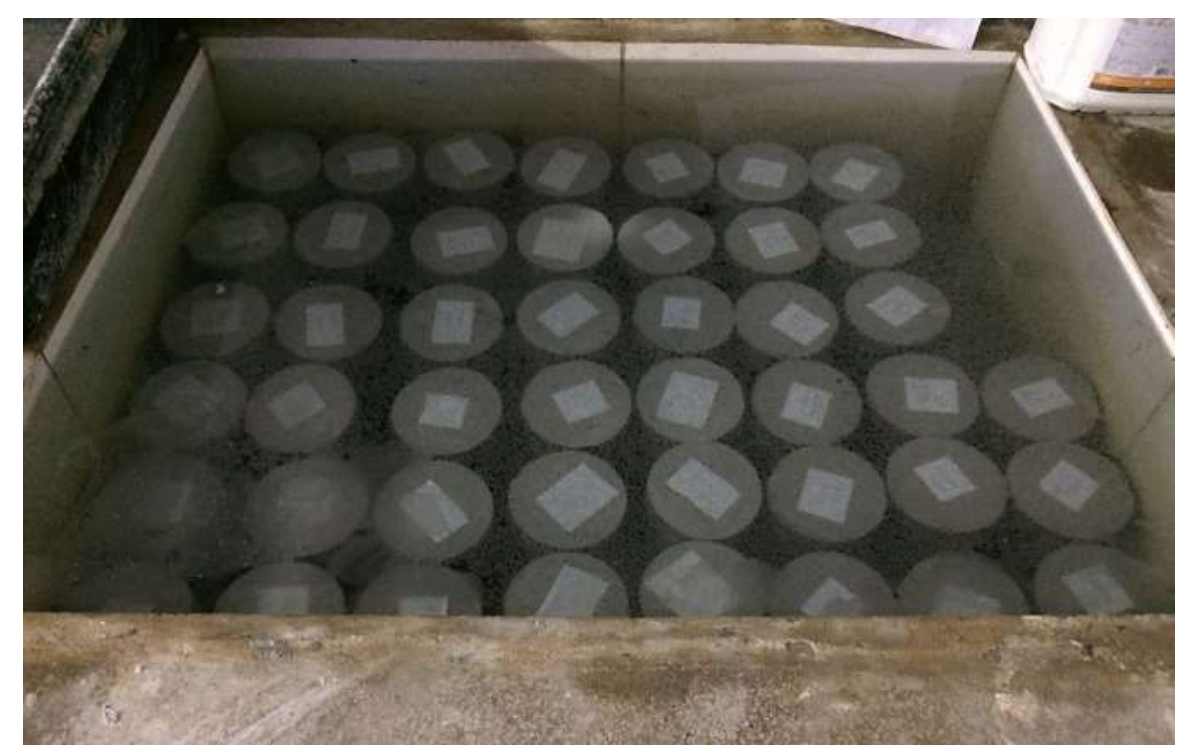

Source: Authors (2020).

The specimens remained in the tank to cure the concrete until their respective breaking dates.

\subsubsection{Compression test}

The compressive strength test was performed according to NBR 5739 (ABNT, 2018), using a manual hydraulic press, according to Figure 11.

Figure 11. Hydraulic press.

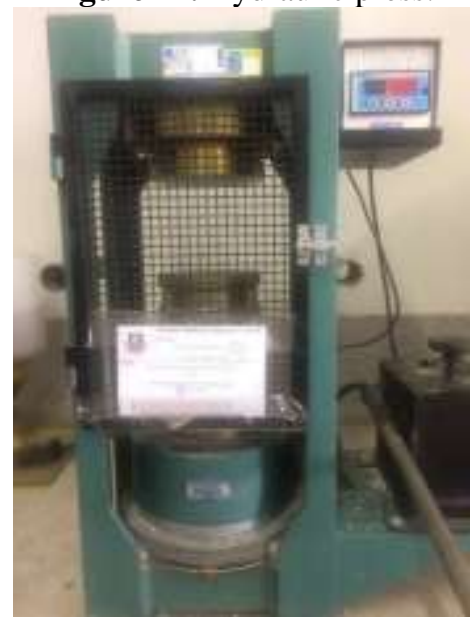

Source: Authors (2020). 
The results found after carrying out the test of rupture of the specimens, are in tons force. This equipment is used to obtain the concrete strength. In this case, this hydraulic press has a mechanical test system.

\section{Results and Discussion}

The main objective of this study was to verify the feasibility of using civil construction and demolition waste as an aggregate by comparing it with a reference concrete.

The granulometry test was performed before the molding of the specimens, in view of the need to leave the residue in a granulometry close to that of the natural coarse aggregate used in the experiment. The results found will be presented by means of graphs and tables.

The RA absorption test was also performed before the molding process, in order to prove the results obtained in the literature. For the test of mechanical resistance to compression, graphs were elaborated from the results found and then their analyzes were made.

\subsection{Granulometry test}

The results of the granulometric analysis of the samples are shown in Table 5, obtained after weighing the material retained in the sieves, for the sand samples.

Table 5. Analysis results for fine aggregate samples.

\begin{tabular}{cccc}
\hline \multicolumn{4}{c}{ Conventional Aggregate Small (CAS) } \\
\hline $\begin{array}{c}\boldsymbol{\emptyset} \text { Sieve } \\
(\mathbf{m m})\end{array}$ & $\begin{array}{c}\text { CAS } \\
(\mathbf{g})\end{array}$ & $\begin{array}{c}\text { Retained } \\
\text { CAS } \\
(\boldsymbol{\%})\end{array}$ & $\begin{array}{c}\text { Accumulated } \\
(\boldsymbol{\%})\end{array}$ \\
\hline $\mathbf{9 , 5}$ & 0,00 & 0,00 & 0,00 \\
\hline $\mathbf{6 , 3}$ & 5,69 & 0,57 & 0,57 \\
\hline $\mathbf{4 , 7 5}$ & 12,27 & 1,23 & 1,80 \\
\hline $\mathbf{2 , 3 6}$ & 76,43 & 7,64 & 9,44 \\
\hline $\mathbf{1 , 1 8}$ & 160,90 & 16,09 & 25,53 \\
\hline $\mathbf{0 , 6}$ & 297,40 & 29,74 & 55,27 \\
\hline $\mathbf{0 , 3}$ & 376,54 & 37,65 & 92,92 \\
\hline $\mathbf{0 , 1 5}$ & 67,55 & 6,77 & 99,69 \\
\hline Base & 3,12 & 0,31 & 100 \\
\hline TOTAL & 1000,00 & 100 & - \\
\hline \multicolumn{5}{c}{ Source: Authors $(2020)}$. \\
\hline
\end{tabular}

With the results obtained in Table 5, it is possible to find the Maximum Characteristic Dimension (MCD) and the Fineness Module (FM). The maximum characteristic dimension of the aggregate corresponding to the nominal opening, in millimeters, of the mesh with an accumulated retained percentage equal to or immediately below $5 \%$ by mass. The $2.36 \mathrm{~mm}$ mesh sieve contains an accumulated percentage of $9.44 \%$, which corresponds to a mass of $76.43 \mathrm{~g}$ of material with a $4.75 \mathrm{~mm}$ granulometry.

Thus, the maximum characteristic dimension of the fine aggregate corresponds to $4.75 \mathrm{~mm}$. The fineness modulus, based on the data, is equivalent to the value of 2.85 , which characterizes the aggregate as being an average sand. The granulometric curve of the fine aggregate, with its respective lower and upper limits, plotted based on the data collected in the test, is as shown in Figure 12. 
Figure 12. Particle size curve of conventional aggregate.

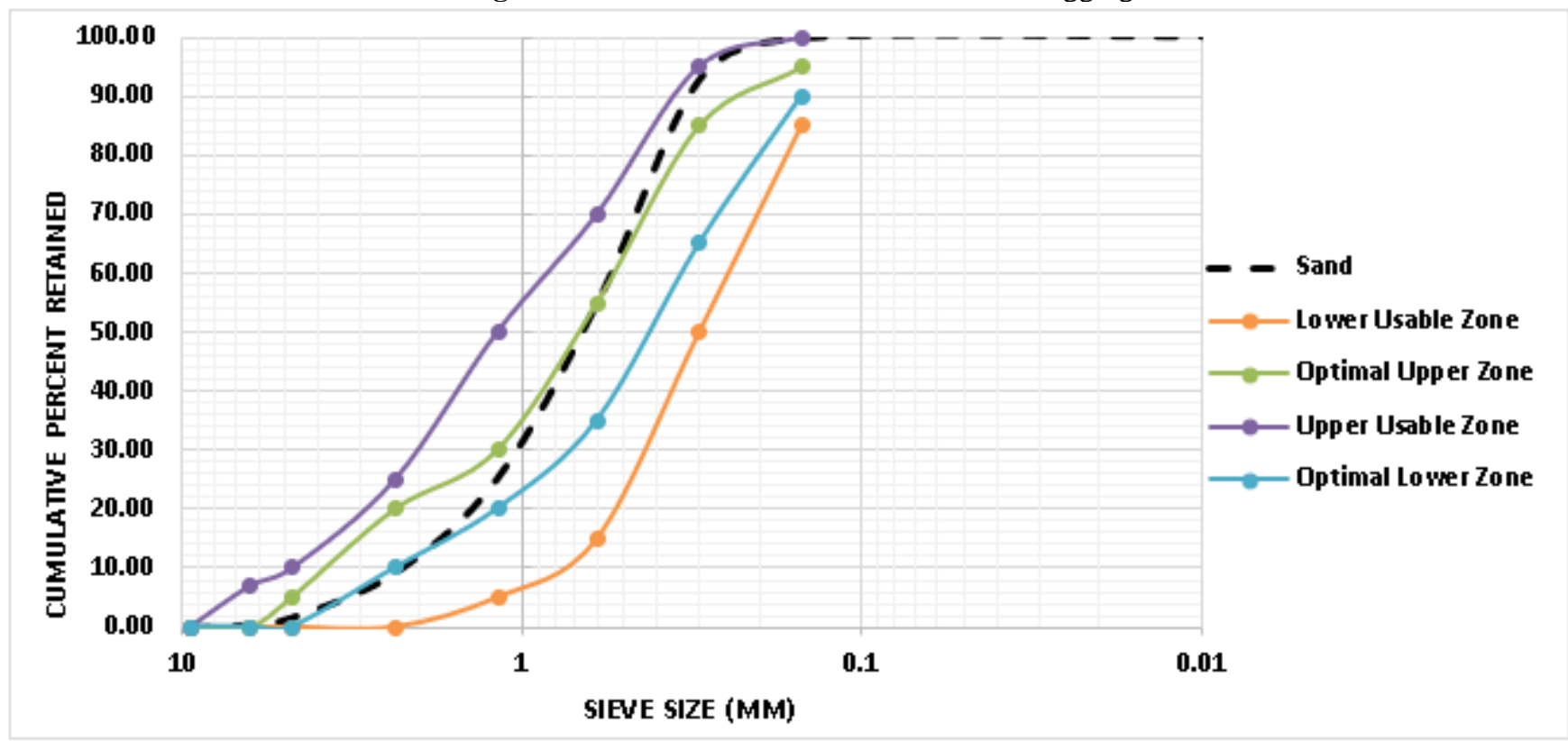

Source: Authors (2020).

According to Figure 12, the granulometric composition of the fine aggregate indicates that the accumulated retained percentages are within the limits established by NBR 7211 (ABNT, 2009). Evidencing a granulometric conformity of the material. The fineness module indicates that the sand is within the optimum zone.

For the determination of unit mass, the procedures established in NBR NM 45 (ABNT, 2006) were followed, however the standard does not define limit values for unit mass of the aggregate. The unit mass was obtained by the relationship between the mass of the aggregate and the volume of the container used in the test, with a value of $1.42 \mathrm{~g} / \mathrm{cm}^{3}$ being found.

The granulometric composition test was also performed for recycled and natural coarse aggregates. The results obtained after weighing each material retained in the sieves, for the samples of recycled coarse aggregate, are shown in Table 6.

Table 6. Analysis results for recycled aggregate samples.

\begin{tabular}{|c|c|c|c|c|c|c|}
\hline \multicolumn{7}{|c|}{ Recycled Coarse Aggregate } \\
\hline $\begin{array}{c}\text { Ø Sieve } \\
(\mathrm{mm})\end{array}$ & $\begin{array}{c}\text { AM1 } \\
(\mathbf{g})\end{array}$ & $\begin{array}{c}\mathbf{A M 2} \\
(\mathbf{g})\end{array}$ & $\begin{array}{c}\text { Retained } \\
\text { AM1 } \\
(\%)\end{array}$ & $\begin{array}{c}\text { Retained } \\
\text { AM2 } \\
(\%)\end{array}$ & $\begin{array}{c}\text { Retained } \\
\text { Average } \\
(\%)\end{array}$ & $\begin{array}{c}\text { Accumulated } \\
\qquad \%)\end{array}$ \\
\hline 25 & 0,00 & 0,00 & 0,00 & 0,00 & 0,00 & 0,00 \\
\hline 19 & 45,36 & 44,78 & 2,27 & 2,24 & 2,25 & 2,25 \\
\hline 12,5 & 1261,68 & 1264,55 & 63,08 & 63,23 & 63,16 & 65,41 \\
\hline 9,5 & 380,08 & 382,20 & 19,00 & 19,11 & 19,06 & 84,47 \\
\hline 6,3 & 219,28 & 215,53 & 10,96 & 10,78 & 10,87 & 95,34 \\
\hline 4,75 & 61,56 & 61,30 & 3,08 & 3,07 & 3,07 & 98,41 \\
\hline 2,36 & 24,98 & 25,11 & 1,25 & 1,26 & 1,25 & 99,66 \\
\hline Base & 7,06 & 6,53 & 0,35 & 0,33 & 0,34 & 100,00 \\
\hline TOTAL & 2000,00 & 2000,00 & 100 & 100 & 100 & - \\
\hline
\end{tabular}

According to Table 6, it is concluded that the recycled coarse aggregate has a maximum aggregate diameter of $19 \mathrm{~mm}$, since it presents an accumulated percentage of less than $5 \%$ by mass. 
It is also noted that the average of the percentage retained accumulated in the screens of the normal series is equal to $284.79 \%$, therefore the fineness module corresponds to the value of 2.85 .

The same test was carried out with the natural coarse aggregate and the results found are shown in Table 7.

Table 7. Analysis results for natural aggregate samples.

\begin{tabular}{|c|c|c|c|c|c|c|}
\hline \multicolumn{7}{|c|}{ Recycled Coarse Aggregate } \\
\hline $\begin{array}{c}\text { Ø Sieve } \\
(\mathrm{mm})\end{array}$ & $\begin{array}{c}\text { AM1 } \\
(\mathrm{g})\end{array}$ & $\begin{array}{c}\text { AM2 } \\
(\mathrm{g})\end{array}$ & $\begin{array}{c}\text { Retained } \\
\text { AM1 } \\
(\%)\end{array}$ & $\begin{array}{c}\text { Retained } \\
\text { AM2 } \\
(\%)\end{array}$ & $\begin{array}{c}\text { Retained } \\
\text { Average } \\
(\%)\end{array}$ & $\begin{array}{c}\text { Accumulated } \\
(\%)\end{array}$ \\
\hline 25 & 0,00 & 0,00 & 0,00 & 0,00 & 0,00 & 0,00 \\
\hline 19 & 0,00 & 0,00 & 0,00 & 0,00 & 0,00 & 0,00 \\
\hline 12,5 & 31,63 & 33,79 & 1,58 & 1,69 & 1,64 & 1,64 \\
\hline 9,5 & 94,96 & 96,83 & 475 & 4,84 & 4,79 & 6,43 \\
\hline 6,3 & 1024,65 & 1021,21 & 51,23 & 51,06 & 51,15 & 57,58 \\
\hline 4,75 & 550,58 & 552,14 & 27,53 & 27,61 & 27,57 & 85,14 \\
\hline 2,36 & 292,60 & 289,50 & 14,63 & 14,48 & 14,55 & 99,70 \\
\hline Base & 5,58 & 6,53 & 0,28 & 0,33 & 0,30 & 100 \\
\hline TOTAL & 2000,00 & 2000,00 & 100 & 100 & 100 & - \\
\hline
\end{tabular}

Based on the values in Table 8, it is observed that the RA presents a percentage of $6.43 \%$ of the total mass tested retained in the $9.5 \mathrm{~mm}$ sieve, that is, an average mass of $95.80 \mathrm{~g}$ of the material, it presents a granulometry $12.5 \mathrm{~mm}$. In this way, the maximum dimension characteristic of the natural aggregate corresponds to $12.5 \mathrm{~mm}$. The fineness modulus obtained from the data was 1.91.

Seeking to perform a comparative analysis of the granulometry of the materials, the curves that describe the behavior of their granulometric compositions, as well as their upper and lower limits, were plotted, based on the results of the screening test. The results for the granulometric analysis of the coarse aggregate are shown in Figure 13.

Figure 13. Granulometric curves of coarse natural and recycled aggregates.

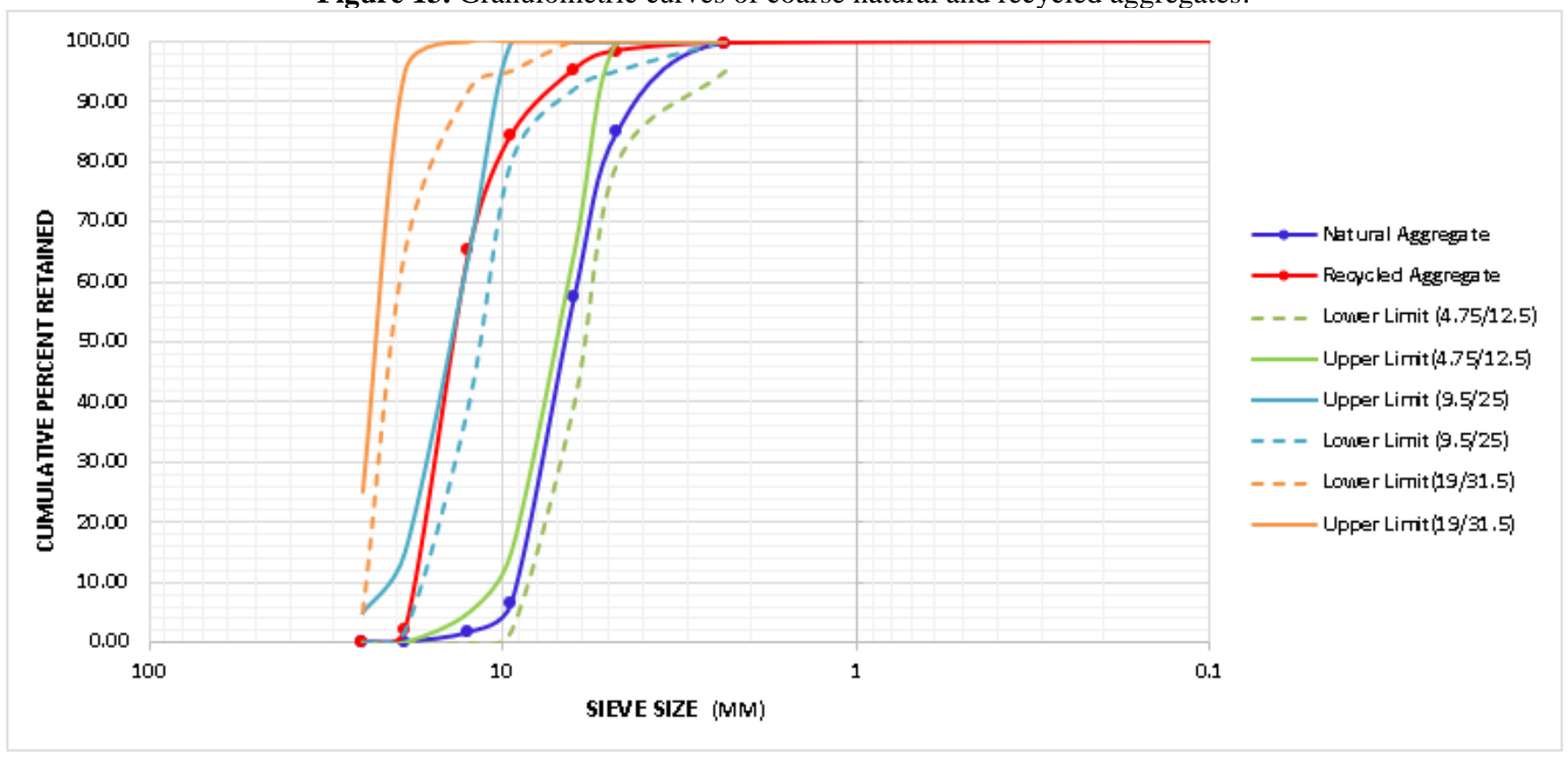

Source: Authors (2020). 
Based on Figure 13, it is observed that both aggregates presented a granulometry within the limits of the specified granulometric bands, based on NBR 7211 (ABNT, 2009). This characteristic, allows a better arrangement between the particles of the aggregate, providing greater packing of the grains. It can be said that the natural coarse aggregate of the sample used, fits in the first granulometric zone $\mathrm{d} / \mathrm{D}$, with a diameter between the sieves of mesh $4,75 \mathrm{~mm}$ and $12,5 \mathrm{~mm}$. Thus, the material sample tested can be classified as gravel \# 0 . The sample of coarse recycled aggregate, on the other hand, fits in the second granulometric zone $\mathrm{d} / \mathrm{D}$, having its diameter between the $9.5 \mathrm{~mm}$ and $25 \mathrm{~mm}$ mesh sieves. Thus, it classifies the material as gravel $n^{\circ} 1$. According to the results, the granulometric curves of the CDW and the natural gravel can be characterized as uniform curves, that is, practically all the grains of the material have the same size.

The values for the unit mass of the CDW aggregate and the natural were $1.03 \mathrm{~g} / \mathrm{cm}^{3}$, and $1.36 \mathrm{~g} / \mathrm{cm}^{3}$, respectively. The reduction in the unit mass of the CDW compared to natural coarse aggregate is due to the reduction in the density of the material itself, the high porosity and irregular shape of the aggregate particles (Cabral, 2007).

The specific mass was obtained by dividing the mass of the aggregate and its volume, excluding the permeable pores. For the aggregate of CDW the specific mass was $1.74 \mathrm{~g} / \mathrm{cm}^{3}$ and for conventional the value of $2.22 \mathrm{~g} / \mathrm{cm}^{3}$ was found.

The specific gravity of the AR tends to be lower when compared to the natural, due to the high number of voids present in the material. The value found was approximately $22 \%$ lower than the conventional aggregate, the same result obtained by Leite (2001), who established a difference of $21 \%$ to $30 \%$.

\subsection{Absorption test}

The data collected based on the performance of the absorption test are shown in Table 8 .

Table 8. Data corresponding to the water absorption test.

\begin{tabular}{cc}
\hline Aggregate & Absorption (\%) \\
\hline RCD & 6,50 \\
\hline Aggregate & 0,5 \\
\hline
\end{tabular}

Source: Authors (2020).

It was found that the AR has a high absorption rate, being 13 times higher than the percentage of the natural aggregate. The standard NBR 15116 (ABNT, 2004), establishes the requirements for the preparation of concretes without structural function, establishing for the recycled aggregates of Class A with an absorption less than or equal to 7\%. Thus, the $\mathrm{RA}$ is within the established limits with a water absorption rate equivalent to $6.50 \%$.

This growth may be related to the content of adhering mortar, which consequently increases the number of pores, which may compromise the line, due to the amount of water that will need to be used. Thus, attention is needed so that resistance is not compromised (Santos et al., 2018).

\subsection{Cone demotion test}

The results found based on the performance of the slaughter test are shown in Table 9. 
Table 9. Data corresponding to the slaughter test.

\begin{tabular}{ccccc}
\hline \multirow{2}{*}{ Replacement } & \multicolumn{4}{c}{ Demotion } \\
\cline { 2 - 5 } & $\begin{array}{c}\text { Measurement 1 } \\
(\mathbf{c m})\end{array}$ & $\begin{array}{c}\text { Measurement 2 } \\
(\mathbf{c m})\end{array}$ & $\begin{array}{c}\text { Measurement 3 } \\
(\mathbf{c m})\end{array}$ & $\begin{array}{c}\text { Average } \\
(\mathbf{c m})\end{array}$ \\
\hline RA - 10\% & 12,0 & 10,5 & 11,5 & 11,3 \\
\hline RA - 20\% & 10,5 & 9,5 & 8,5 & 9,5 \\
\hline RA - 30\% & 9,0 & 8,0 & 10,0 & 9,0 \\
\hline RA - 40\% & 9,0 & 9,5 & 8,5 & 9,0 \\
\hline RA - 50\% & 9,5 & 8,5 & 8,0 & 8,67 \\
\hline RA - 100\% & 8,0 & 8,5 & 8,0 & 8,17 \\
\hline
\end{tabular}

Source: Authors (2020).

Based on the values, it was possible to observe that there was a reduction in the abatement as the substitution levels increased.

According to studies carried out by Leite (2001), the relationship between the water/cement factor and consistency, shows an inverse behavior when compared to conventional concretes. This behavior can be justified considering that mixtures with a higher water/cement ratio, have a lower amount of cement, and thus tend to be rougher and have greater locking.

Also, in this same study, it was found that the higher the content of recycled coarse aggregate, the lower the abatement of concrete mixtures. It was found that the combination of low cement consumption of poor traces and high proportions of rough and irregular aggregates, tend to increase the fall in the abatement values (Leite, 2001).

\subsection{Compressive strength test}

The performance of the molding and curing procedures for concrete specimens followed the parameters established in NBR 5738 (ABNT, 2015). After the molding procedures, the specimens were subjected to wet curing, until the rupture date at 7, 14 and 28 days, to be evaluated the resistance over time.

Compressive strength is a sensitive property, usually capable of indicating an idea about the quality of the concrete, the dosage and its inputs, since it is directly linked to the structure of the cement paste (Neville \& Brooks, 2013). The resistance of concrete produced with CDW aggregates will be lower than that of concrete with natural aggregate, depending on the porosity. The values used to compose the results correspond to the average of the resistance obtained between the three samples, broken for each age. The results for the compression test with rupture at 7 days are shown in Figure 14 . 
Figure 14. Results of the compressive strength test at 7 days.

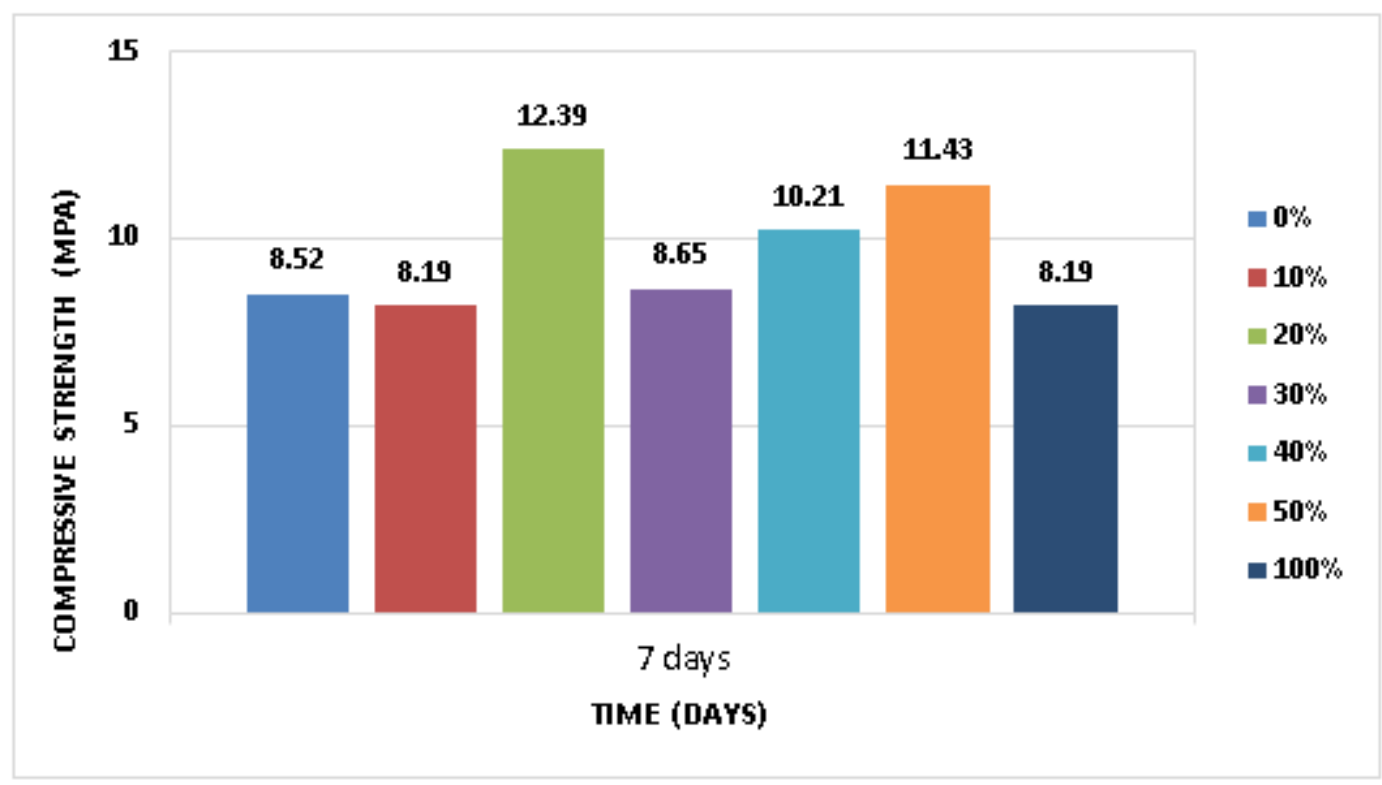

Source: Authors (2020).

The specimens with 7 days of curing showed resistance to compression in the strokes with CDW, values very close to those of conventional concrete. There is a difference in strength for the $20 \%$ and $50 \%$ substitutions, which presented average strengths of $12.39 \mathrm{MPa}$ and $11.43 \mathrm{MPa}$, being higher than the concrete used as a reference, with 8.52 MPa. The results found for the 14-day trial are shown in Figure 15.

Figure 15. Results of the compressive strength test at 14 days.

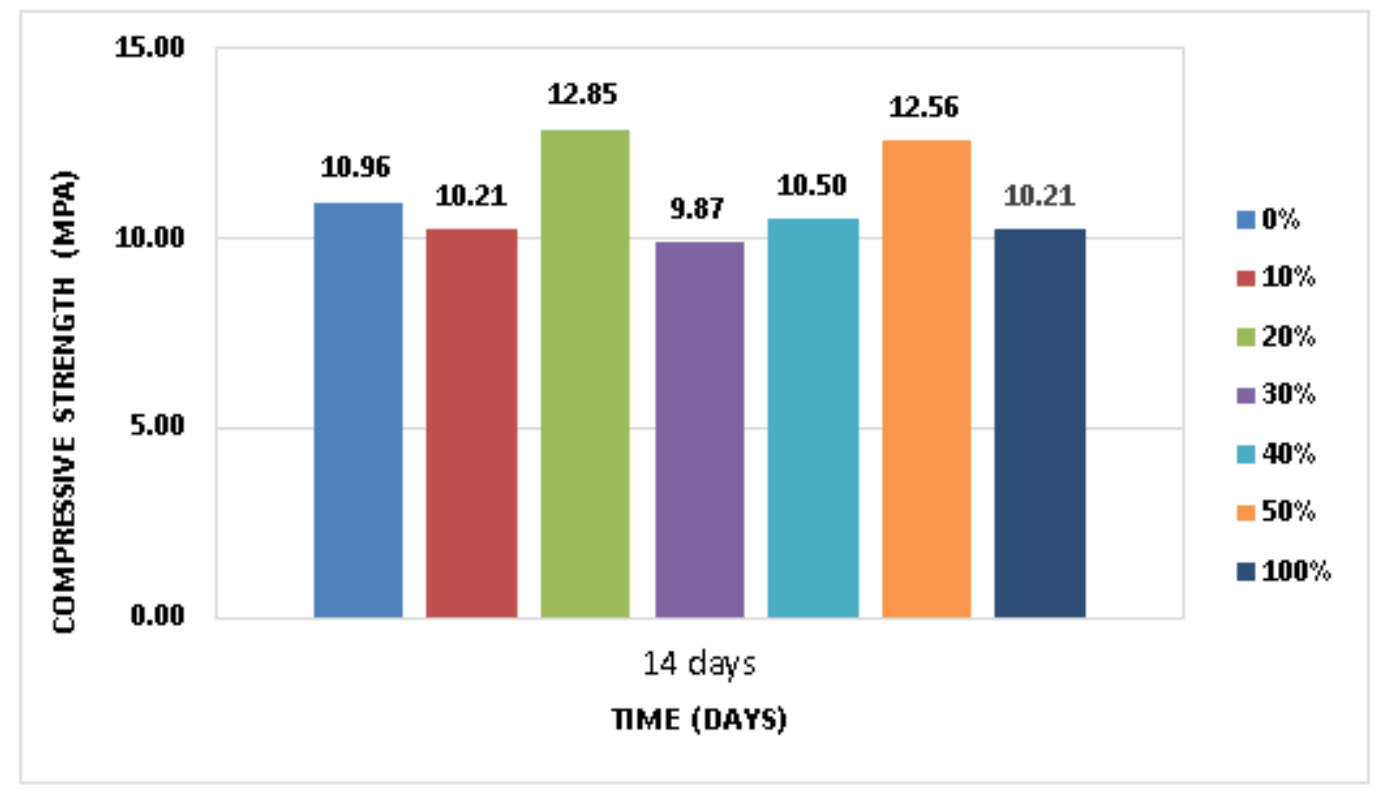

Source: Authors (2020). 
Taking as a reference the results found from the rupture of the specimens, it is noted that there was a slight increase in the compressive strength values when compared to the age of 7 days. During this period there was no increase of more than $2 \mathrm{MPa}$.

From the 7 th day to the 14 th day, the strength of conventional concrete increased the average from $8.52 \mathrm{MPa}$ to 10.96 $\mathrm{MPa}$, while the strength of recycled concrete remained practically constant.

However, concrete with $20 \%$ substitution, despite having only a small strength gain, varying from $12.39 \mathrm{MPa}$ to 12.85 $\mathrm{MPa}$, still remains with a higher resistance than the reference.

Regarding the $100 \%$ substitution, it is possible to notice that it has the lowest average, when purchased at the other values. This behavior was already expected, since the higher the substitution levels, the lower the resistance values will be.

The results for compressive strength at 28 days are shown in Figure 16.

Figure 16. Results of the compressive strength test at 28 days.

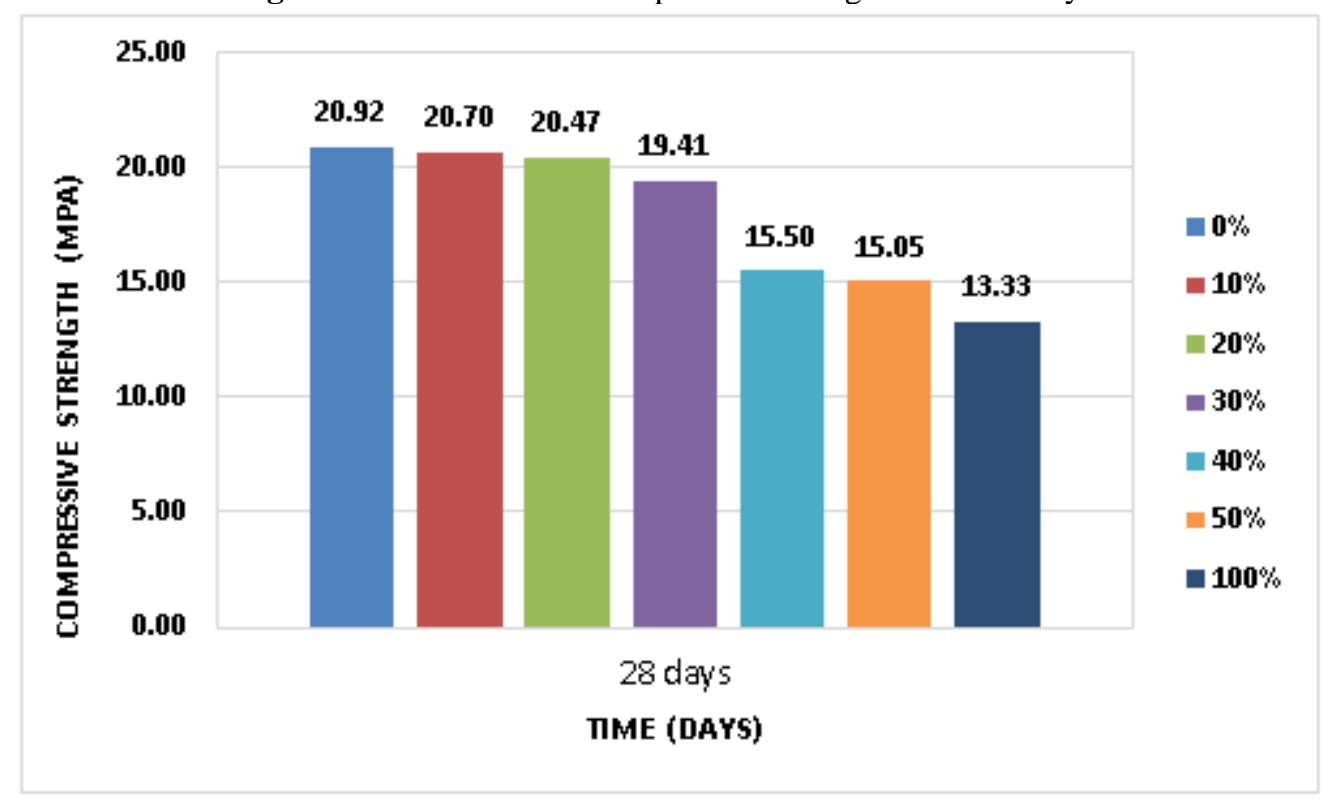

Source: Authors (2020).

According to the results obtained, it appears that the reference concrete has an average resistance of $20.92 \mathrm{MPa}$ and that the substitutions of $10 \%$ and $20 \%$ achieved a performance very close to this result, with the averages of $20.70 \mathrm{MPa}$ and 20.47 MPa, respectively. In this way, because they result in a concrete with the same performance as the reference concrete, these substitutions become viable.

In his studies, Levy (2001), proved that the use of concrete and masonry residues with a 20\% substitution content, does not have a negative impact on the strength of concrete with RA, in relation to the reference.

At the end of the 28 days, the $30 \%$ substitution was very close to the limit, with a resistance in the order of 19.41 MPa. The substitutions with $40 \%, 50 \%$ and $100 \%$ of RA, however, did not present the required resistances. The maximum strength found for concrete with $100 \%$ replacement was $13.33 \mathrm{MPa}$ and for conventional concrete $20.92 \mathrm{MPa}$, almost twice as high as concrete with AR. Corroborating with Etxeberria et al. (2007), a decrease of $20 \%$ to $25 \%$ in the compressive strength of the concrete was obtained with substitution of $100 \%$ of recycled coarse aggregate.

As expected, the increase in the substitution of the natural coarse aggregate for the CDW aggregate does not imply higher values for compression. This is because the absorption and the void index increase according to the degree of 
substitution, resulting in a structure and distribution of pores that do not favor the system. This low resistance can also be associated with the composition of the waste that depends on the source of origin (Leite, 2001).

\section{Conclusion}

Civil construction is responsible for generating several environmental impacts, from the extraction of natural resources to the completion of the work and later its demolition. A viable destination for the reuse of CDW is its use in replacing the natural aggregate as a raw material for making concrete.

From the characterization tests of the aggregates used, it was possible to verify, based on the granulometric analysis, that the accumulated retained percentages of the CDW are within the limits established in the norm.

As for the water absorption test, although the value obtained for the RA is higher than the conventional one, demonstrating its high porosity, no negative influence was observed on the compressive strength of the concrete.

With regard to specific mass and unit mass, the values found for the CDW aggregate, were lower when purchased from the natural aggregate. These results prove that the amount of mortar adhered, influences these properties.

The characterization of the RA performed here confirmed the literature, showing that their properties undergo modifications due to several factors, such as origin, composition and crushing method.

In the compressive strength test, after 28 days of curing, the traces for the 10\% and $20 \%$ CDW substitutions showed performances similar to conventional concrete (20.92 MPa), with an average strength of $20.70 \mathrm{MPa}(-1.05 \%)$ and $20.47 \mathrm{MPa}$ ($2.15 \%)$ respectively. The trait for $100 \%$, however, presented a lower performance, with only $13.33 \mathrm{MPa}(-36.28 \%)$.

In general, it is concluded that the dosage and production of recycled concrete is feasible with up to $20 \%$ recycled concrete aggregate, making use of the IPT/EPUSP method to obtain concrete that has good mechanical performance, with respect to resistance to compression.

In view of this, as a suggestion for future work, it is possible to indicate studies aimed at analyzing the durability of concretes produced with CDW aggregates, as well as analyzing the possibility of applying the materials used in this study, for the production of structural concrete.

\section{References}

Aragão, H. G., Lima, F. B., Lima, P. R. L., Leite, M. B. \& Nagahama, K. J. (2007). Aplicação do concreto reciclado de RCD em vigas para lajes prémoldadas. Anais do $49^{\circ}$ CBC. https://www.researchgate.net/publication/318362896

Associação Brasileira de Cimento Portland. (2019). Cimento Portland CP II. 2019. https://www.abcp.org.br/cms/perguntas-frequentes/cimento-portland-cp-iinbr-11578/ >.

Associação Brasileira de Normas Técnicas. (2015). NBR 12655: Concreto cimento Portland - preparo, controle, recebimento e aceitação - Procedimento.

Associação Brasileira de Normas Técnicas. (2004). NBR 15116: Agregados reciclados de resíduos sólidos da construção civil - Utilização em pavimentação e preparo de concreto sem função estrutural - Requisitos.

Associação Brasileira de Normas Técnicas. (2015). NBR 5738: Concreto -procedimento de moldagem e cura de corpos de prova.

Associação Brasileira de Normas Técnicas. (2018). NBR 5739: Concreto - Ensaio de compressão de corpos de prova cilíndricos

Associação Brasileira de Normas Técnicas. (2009). NBR 7211: Agregados para concreto - Especificação.

Associação Brasileira de Normas Técnicas. (2003). NBR NM 248: Agregados - Determinação da composição granulométrica.

Associação Brasileira de Normas Técnicas. (2009). NBR NM 53: Agregado graúdo - determinação da massa específica, massa específica aparente e absorção de água.

Associação Brasileira de Normas Técnicas. (1998). NBR NM 67: Concreto - Determinação da consistência pelo abatimento do tronco de cone.

Associação Brasileira de Normas Técnicas. (2006). NBR NM 45: Agregados - Determinação da massa unitária e do volume de vazios. 
Associação Brasileira para Reciclagem de Resíduos da Construção Civil e Demolição. (2016). Resíduos da construção e demolição: geração de emprego e renda. http://abrecon.org.br/residuos-da-construcao-e-demolicao-geracao-de-emprego-e-renda

Cabral, A. E. B. (2007). Modelagem de propriedades mecânicas e de durabilidade de concretos produzidos com agregados reciclados, considerando-se a variabilidade da composição do RCD. Tese de Doutorado em Ciências da Engenharia Ambiental. Escola de Engenharia de São Carlos da Universidade de São Paulo. São Carlos, Brasil. 10.11606/T.18.2007.tde-21102007-164548

Cabral, A. E. B. \& Moreira, K. M. V. (2011). Manual sobre os Resíduos Sólidos da Construção Civil. Sinduscon.

Conselho Nacional do Meio Ambiente. (2002). Resolução CONAMA $n^{o}$ 307, de 5 de julho de 2002. http://www.mma.gov.br/port/conama/res/re s02/res30702.html

Etxeberria, M., Vázquez, E.; Marí, A. \& Barra, M. (2007). Influence of amount of recycled coarse aggregates and production processon properties of recycled aggregate concrete. Cement and Concrete Research, 37, 735-742. https://doi.org/10.1016/j.cemconres.2007.02.002

Fonseca, A. P. (2006). Estudo comparativo de concretos com agregado graúdo reciclado de telha cerâmica e agregado graúdo natural. Dissertação de mestrado. apresentada à Faculdade de Engenharia Civil da Universidade Federal de Uberlândia. Uberlândia, Brasil. https://repositorio.ufu.br/handle/123456789/14205

Frotté, C., Núbila, C. S. A. D., Nagalli, A., Mazer, W., Macioski, G. \& Oliveira, L. O. S. (2017). Estudo das propriedades físicas e mecânicas de concreto com substituição parcial de agregado natural por agregado reciclado proveniente de RCD. Revista Matéria. 22(2). 10.1590/S1517-707620170002.0143

Helene, P. \& Terzian, P. (1993). Manual de dosagem e controle do concreto. Pini.

Helene, P \& Tutikian, B. F. (2011). Dosagem de concretos de cimento Portland. Concreto: Ciência e Tecnologia. IBRACON.

Isaia, C. G. (2011). Concreto: Ciência e Tecnologia. IBRACON.

John, V. M. \& Agopyan, V. (2013). Reciclagem de resíduos da construção. Seminário Reciclagem de Resíduos Sólidos Domiciliares. Escola Politécnica da USP, São Paulo.

Karpinsk, L. A., Pandolfo, A., Reineher, R., Guimarães, J. C. B., Pandolfo, L. M. \& Kurek, J. (2009). Gestão diferenciada de resíduos da construção civil: uma abordagem ambiental. Revistas Unisinos. EDIPUCRS. http://revistas.unisinos.br/index.php/estudos_tecnologicos/article/view/5494/2728

Leite, M. B. (2001). Avaliação de propriedades mecânicas de concretos produzidos com agregados reciclados de resíduos de construção e demolição. Tese de Doutorado. Porto Alegre: Universidade Federal do Rio Grande do Sul. http://hdl.handle.net/10183/21839

Levy, S. M. (2001). Contribuição ao estudo da durabilidade de concretos, produzidos com resíduos de concreto e alvenaria. Tese de Doutorado em Engenharia de Construção Civil. EPUSP. https://repositorio.usp.br/item/001231349

Neville, A. M. \& Brooks, J. J. (2013). Tecnologia do Concreto. (2a ed.), Bookman.

Otsuki, N., Miyazato, S. \& Yodsudjai, W. (2003). Influence of Recycled Aggregate on Interfacial Transition Zone, Strength, Chloride Penetration and Carbonation of Concrete. Journal of Materials in Civil Engineering, 15, 443. https://doi.org/10.1061/(ASCE)0899-1561(2003)15:5(443)

Pelissari, V. (2016). Propriedades de concretos produzidos através da utilização de agregados reciclados de concreto. Dissertação de Mestrado. Curitiba: Universidade Tecnológica Federal do Paraná, Brasil. http://repositorio.utfpr.edu.br/jspui/handle/1/1869

Rahal, K. (2007). Mechanical properties of concrete with recycled coarse aggregate. Building and Environment, 42, 407-415. https://doi.org/10.1016/j.buildenv.2005.07.033

Pereira, A. S., Shitsuka, D. M., Parreira, F. J., \& Shitsuka, R. (2018). Metodologia da Pesquisa Científica. UFSM.

Santos, C. J. R., Lima, D. A., Silva Junior, E. R., Batista, L. S. \& Ferreira, M. L. M. (2018). Estudo do comportamento mecânico do concreto a partir da utilização do RCD como agregado graúdo. Congresso Sul Americano de resíduos sólidos e sustentabilidade, http://www.ibeas.org.br/conresol/conresol2018/VII-027.pdf

Silva, A. S., Souza Filho, W. B., Santos, C. M. S \& Araújo, A. P. D. (2017). Análise das perdas de materiais no serviço de alvenaria: estudo de caso realizado em obras de edificações residenciais de pequeno porte. Revista Principia - Divulgação Científica e Tecnológica do IFPB. ISSN 2447-9187. 35, 90-102. $10.18265 / 1517-03062015 \mathrm{v} 1 \mathrm{n} 35 \mathrm{p} 90-102$

Silva, M. B. L. (2014). Novos materiais à base de resíduos de construção e demolição (RCD) e resíduos de produção de cal (RPC) para uso na construção civil. Dissertação de Mestrado. Curitiba: Universidade Federal do Paraná, Brasil. http://hdl.handle.net/1884/35321

Souza, U. E. L. (2005). Como reduzir perdas nos canteiros: Manual de gestão do consumo de materiais na construção civil. Pini, Brasil.

Torgal, P. F., Jalali, S., Labrincha, J., \& John, V. M. (2013). Eco-Efficient Concrete. Woodhead Publishing. https://www.elsevier.com/books/eco-efficientconcrete/pacheco-torgal/978-0-85709-424-7

Xiao, J, Li, J. \& Zhang, C. (2005). Mechanical properties of recycled aggregate concrete under uniaxial loading. Cement and Concrete Research, 35, 11871194. https://doi.org/10.1016/j.cemconres.2004.09.020

Xiao, J., Zhang, K. \& Akbarnezhad, A. (2018). Variability of stress-strain relationship for recycled aggregate concrete under uniaxial compression loading, 181, 753-771. https://doi.org/10.1016/j.jclepro.2018.01.247 